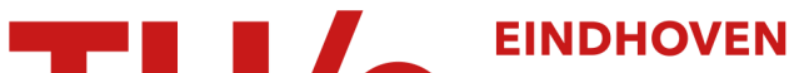 UNIVERSITY OF TECHNOLOGY
}

\section{A green COVID-19 recovery of the EU basic materials sector}

\section{Citation for published version (APA):}

Chiappinelli, O., Gerres, T., Neuhoff, K., Lettow, F., de Coninck, H., Felsmann, B., Joltreau, E., Khandekar, G., Linares, P., Richstein, J., Sniegocki, A., Stede, J., Wyns, T., Zandt, C., \& Zetterberg, L. (2021). A green COVID19 recovery of the EU basic materials sector: identifying potentials, barriers and policy solutions. Climate Policy, 21(10), 1328-1346. https://doi.org/10.1080/14693062.2021.1922340

DOI:

10.1080/14693062.2021.1922340

Document status and date:

Published: 01/01/2021

\section{Document Version:}

Publisher's PDF, also known as Version of Record (includes final page, issue and volume numbers)

\section{Please check the document version of this publication:}

- A submitted manuscript is the version of the article upon submission and before peer-review. There can be important differences between the submitted version and the official published version of record. People interested in the research are advised to contact the author for the final version of the publication, or visit the DOI to the publisher's website.

- The final author version and the galley proof are versions of the publication after peer review.

- The final published version features the final layout of the paper including the volume, issue and page numbers.

Link to publication

\section{General rights}

Copyright and moral rights for the publications made accessible in the public portal are retained by the authors and/or other copyright owners and it is a condition of accessing publications that users recognise and abide by the legal requirements associated with these rights.

- Users may download and print one copy of any publication from the public portal for the purpose of private study or research.

- You may not further distribute the material or use it for any profit-making activity or commercial gain

- You may freely distribute the URL identifying the publication in the public portal.

If the publication is distributed under the terms of Article 25fa of the Dutch Copyright Act, indicated by the "Taverne" license above, please follow below link for the End User Agreement:

www.tue.nl/taverne

Take down policy

If you believe that this document breaches copyright please contact us at:

openaccess@tue.nl

providing details and we will investigate your claim. 


\section{Climate Policy}

\section{A green COVID-19 recovery of the EU basic materials sector: identifying potentials, barriers and policy solutions}

Olga Chiappinelli, Timo Gerres, Karsten Neuhoff, Frederik Lettow, Heleen de Coninck, Balázs Felsmann, Eugénie Joltreau, Gauri Khandekar, Pedro Linares, Jörn Richstein, Aleksander Śniegocki, Jan Stede, Tomas Wyns, Cornelis Zandt \& Lars Zetterberg

To cite this article: Olga Chiappinelli, Timo Gerres, Karsten Neuhoff, Frederik Lettow, Heleen de Coninck, Balázs Felsmann, Eugénie Joltreau, Gauri Khandekar, Pedro Linares, Jörn Richstein, Aleksander Śniegocki, Jan Stede, Tomas Wyns, Cornelis Zandt \& Lars Zetterberg (2021) A green COVID-19 recovery of the EU basic materials sector: identifying potentials, barriers and policy solutions, Climate Policy, 21:10, 1328-1346, DOI: 10.1080/14693062.2021.1922340

To link to this article: https://doi.org/10.1080/14693062.2021.1922340
(2) 2021 The Author(s). Published by Informa UK Limited, trading as Taylor \& Francis Group

曲 Published online: 18 May 2021.

Џlll Article views: 3073

View Crossmark data ¿

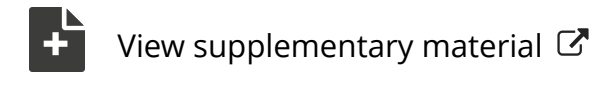

Submit your article to this journal ¿
View related articles $\sqsubset$

Citing articles: 3 View citing articles $\sqsubset$ 


\title{
A green COVID-19 recovery of the EU basic materials sector: identifying potentials, barriers and policy solutions*
}

\author{
Olga Chiappinelli (iD) ${ }^{a}$, Timo Gerres (D) ${ }^{b}$, Karsten Neuhoff (iD ${ }^{a, c}$, Frederik Lettow ${ }^{a}$, \\ Heleen de Coninck (D) d,e, Balázs Felsmann (D) ${ }^{f}$, Eugénie Joltreau (D) ${ }^{g}$, Gauri Khandekarh, \\ Pedro Linares (iD) ${ }^{b}$, Jörn Richstein (1) ${ }^{a}$, Aleksander Śniegocki ${ }^{i}$, Jan Stede (1) ${ }^{a}$, Tomas Wyns ${ }^{h}$, \\ Cornelis Zandt $\mathrm{t}^{\mathrm{j}}$ and Lars Zetterberg ${ }^{\mathrm{k}}$
}

\begin{abstract}
${ }^{a}$ Climate Policy Department, German Institute for Economic Research (DIW Berlin), Berlin, Germany; ${ }^{\mathrm{b}}$ Institute for Research in Technology, ICAI, Comillas Pontifical University, Madrid, Spain; ' Institute for Economics and Law, Technische Universität Berlin, Berlin, Germany; ${ }^{\mathrm{d}}$ Technology Innovation and Society Group, Eindhoven University of Technology, Eindhoven, Netherlands; e Department of Environmental Science, Radboud University, Nijmegen, Netherlands; ${ }^{\mathrm{f}}$ Regional Centre for Energy Policy Research, Corvinus University of Budapest, Budapest, Hungary; ${ }^{9}$ LEDa (CGEMP), PSL Research University - University Paris-

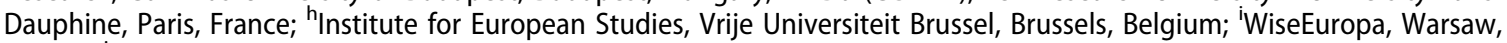
Poland; 'Institute for Management Research \& Department of Environmental Science, Radboud University, Nijmegen, Netherlands; ${ }^{\mathrm{IV}}$ L Swedish Environmental Research Institute, Stockholm, Sweden
\end{abstract}

\begin{abstract}
This paper explores climate-friendly projects that could be part of the COVID-19 recovery while jump-starting the transition of the European basic materials industry. Findings from a literature review on technology options in advanced development stages for climate-friendly production, enhanced sorting, and recycling of steel, cement, aluminium, and plastics, are combined with insights from interviews with 31 European stakeholders in these sectors about the practical and economic feasibility of these technology options. Results indicate that with an estimated investment of 28.9 billion Euros, up to $20 \%$ of EU's basic materials could be produced through low-emission processes or additional recycling by 2025 with technologies that are commercially available or at pilot scale today. However, our stakeholder consultation also shows that in order to make these short-term investments viable, six main barriers need to be addressed, namely: (i) the lack of effective and predictable carbon pricing, (ii) the limited availability of affordable green electricity, (iii) the lack of a regulatory framework for circularity, (iv) low technology market readiness and funding, ( $v$ ) the lack of infrastructure for hydrogen, $\mathrm{CO}_{2}$ and power, and (vi) the lack of demand for climate-friendly and recycled materials. Based on these insights, the paper proposes elements of a policy package that can create a framework favourable for investments in these technologies; these policies should ideally accompany the recovery package to give credibility to investors that the business case will last beyond the recovery period.
\end{abstract}

Key policy insights:

- Technologies for climate-friendly materials production, sorting and recycling can be supported as part of the recovery package but require an enabling policy framework.

\section{ARTICLE HISTORY}

Received 27 November 2020

Accepted 22 April 2021

\section{KEYWORDS}

Green COVID-19 recovery; industrial decarbonization; basic materials; policy package; EU green deal; technology readiness

CONTACT Olga Chiappinelli ochiappinelli@diw.de

(4) Supplemental data for this article can be accessed at https://doi.org/10.1080/14693062.2021.1922340.

* This paper extends the analysis contained in the report by Neuhoff et al. 'Investments in climate-friendly materials to strengthen the recovery package', Climate Strategies Report, June 2020.

(c) 2021 The Author(s). Published by Informa UK Limited, trading as Taylor \& Francis Group

This is an Open Access article distributed under the terms of the Creative Commons Attribution License (http://creativecommons.org/licenses/by/4.0/), which permits unrestricted use, distribution, and reproduction in any medium, provided the original work is properly cited. 
- Combining continued free allocation with a Climate Contribution within the EU ETS can enhance economic viability of climate-friendly options.

- Project-based Carbon Contracts for Difference can eliminate carbon price uncertainty for climate-friendly processes.

- Auctions for publicly backed Contracts for Difference and Power Purchasing Agreements can guarantee price-stability of low-emission electricity.

- Green public procurement and public-private partnerships can provide infrastructure for hydrogen, $\mathrm{CO}_{2}$ and electricity while creating demand for climate-friendly materials.

- Revising regulations on product design and end-of-life emissions can improve sorting and recycling incentives.

\section{Introduction}

In response to the economic crisis caused by the COVID-19 pandemic, the European Union and its member states are launching a wide range of economic stimulus measures. This recovery plan should not only achieve the short-term objective of boosting the economy and creating jobs, but additionally deliver climate and long-term economic benefits (von der Leyen, 2020). Supporting climate-friendly investments in the basic material sector, namely steel, cement, chemicals, and aluminium (IEA, 2020), can be key for a green economic recovery. However, this would require public funding to fulfil three conditions (Kröger et al., 2020): first, to target novel production processes, sorting, and recycling technologies, to trigger investments with high economic return. Second, the implementation of many of the projects needs to be timely, meaning that technologies are 'shovel-ready', i.e. in an advanced development stage. Lastly, recovery support needs to be temporary, i.e. sufficient to leverage private investments to replace public funding after the recovery period. This means that the regulatory environment must provide long-term incentives and risk-hedging instruments, which ensures that business cases for new investments are robust beyond the recovery period.

At a first glance, the basic material sector does not seem to be a good fit for a timely and temporary recovery policy. Production processes are technologically mature and highly standardized, while equipment is capital intensive and has a long design life of 15-50 years (Åhman et al., 2016). Energy consumption is a principal cost component, ranging from $24 \%$ of the gross operating surplus in refineries to $79 \%$ in the steel industry, making basic material production highly emission intensive, accounting for $57 \%$ of all emissions covered by the European Emission Trading System (EU ETS) (de Bruyn et al., 2020). Furthermore, basic materials are internationally traded commodities with little differentiation in product characteristics, which makes it difficult to develop business cases for climate-friendly production with increased capital and operational expenditures (Bataille et al., 2018).

The high emissions of basic materials have brought this sector in the spotlight of policymakers. Long-term net-zero emissions objectives within the EU require a deep transformation of the sector until 2050 and have triggered industrial stakeholders to increase research and development (R\&D) and envision climate-friendly sectoral strategies (CEMBUREAU, 2020b; EA, 2019; EUROFER, 2019; VCl, 2019). As such, the recovery plan is essential to ensure that the EU basic materials sector is on track to reach the climate targets. An economic recovery that is not aligned with decarbonization targets would trigger a carbon-intensive technological path dependence, which would increase the future cost to switch back to a low-emission trajectory (Grubb, 2014).

In this context, this paper explores whether and to what extent low-emission options are shovel-ready, such that recovery investments in these technologies could jump-start the transition of the European basic materials industry. The focus is solely on options with high technological readiness that are available for near-time implementation. Options identified in the literature are compared to stakeholder feedback about practical and economic feasibility, and the potential scale of investment costs is quantified. For this purpose, we conducted 31 interviews with industrial experts about climate-friendly production process alternatives, enhanced sorting and recycling and the barriers hindering their deployment in the steel, cement, aluminium, and plastics industry. We then review elements of a policy package, which could help to overcome these barriers. Such 
policies would need to accompany the recovery plan on a national and European level to establish a robust investments framework beyond the recovery period. The analysis thereby contributes to the scientific knowledge on opportunities and barriers about the near-term implementation of low-emission technologies in the basic material sector. Unlike previous studies, e.g. on the Dutch concrete sector (Wesseling \& Van der Vooren, 2017) and chemical industry (Janipour et al., 2020) or the German industry (Büttner et al., 2020), this work analyses the multinational cross-sectorial dimension of industrial transition, taking into consideration technological barriers and the industrial stakeholder perspective, to evaluate feasible policy actions in response to the COVID19 pandemic and beyond.

The paper is structured as follows: Section 2 describes the methodologies adopted for the analysis. Section 3 identifies technology options, which could be supported through the recovery package. Section 4 discusses perceived barriers to investments in these technologies. Section 5 identifies the policy needs based on the findings in Sections 3 and 4 and discusses potential policy solutions. Section 6 concludes.

\section{Methods}

We conducted 31 semi-structured interviews with industry experts across 6 European countries, i.e. Germany, Netherlands, Belgium, Spain, Hungary, and Poland (see Table 1 in Annex 1.1 for categorization of interviews). The interviews were conducted by phone or video-call between 11th of May and 23rd of September 2020. Using a standardized questionnaire (Annex 1.1), we asked our interviewees about the most promising technology options for the transition of their sector, how their accelerated deployment could contribute to an economic recovery and what barriers they see for their implementation. Interviews were conducted in the national language of the interviewee, recorded, transcribed, or summarized, and upon request sent to interviewees for review. Coding of all interviews was implemented by one researcher, based on an English translation of a summarized version of the transcripts. The researcher then peer-reviewed results with researchers conducting the interviews. To respect confidentiality, this paper does not refer to individual interviews.

Section 3 compares findings from these interviews with information provided in the literature about available technology options, comparing the best available processes used commercially, today, with low-emission process and recycling alternatives with high technological readiness level (TRL) ${ }^{1}$ and options mentioned by interviewees. Existing reviews focus primarily on technology options for deep decarbonization that aim for raw material substitution, zero-emission fuel sources and closed-loop recycling (Gerres et al., 2019a; Rissman et al., 2020). Advancements in material efficiency and improved repair and reuse are beyond the scope of this analysis. The technical feasibility and investment costs of adjacent new infrastructure, e.g. for the supply of hydrogen or $\mathrm{CO}_{2}$ transport, is out of the scope of this analysis. Nevertheless, the access to such infrastructures is analysed as a possible barrier for technological implementation.

Interviewees were asked an open question on perceived barriers. For the analysis in Section 4 the barriers were ranked in a stepwise approach. First, barriers were categorized by identifying similar responses across interviewees. Second, an interviewee-specific ranking of barriers was determined based on the emphasis on specific barriers, whether it was mentioned first or only later on and how often, and how important it was regarded to be. Third, the share of interviewees that mentioned a specific barrier as one of the main three was determined for each category. The final ranking reflects how often the respective barrier was one of the three main barriers for the interviewees.

\section{Technology options for recovery investment}

Investments in the basic material sector need to be timely if included in the economic recovery package. This limits the support to those technology options which are or can be commercially available within the next years. In the following we present a techno-economic overview of the best available technologies (BAT) and compare them with climate-friendly process and recycling alternatives with high TRL. Special emphasis is placed on their energy consumption since all basic materials production processes have in common that fossil fuels and feedstock are the main operational cost drivers. 


\subsection{Steel}

Primary steel is produced by reducing iron ore with coal in blast furnaces-basic oxygen furnaces (BF-BOF). Modern installations require about $16.7 \mathrm{GJ} / \mathrm{t}$, of which $95 \%$ is thermal energy (Chan \& Kantamaneni, 2015) with on average $1.9 \mathrm{tCO}_{2}$ emitted per ton of steel slab in Europe (EUROFER, 2013). BAT technology for steel recycling, which accounted for 40\% of EU production in 2018 (World Steel, 2019), is about 75\% less energy and emission intensive than primary steel making (Chan \& Kantamaneni, 2015). While smelting in electric arc furnaces (EAF) is electrified, natural gas is normally used for hot rolling processes. Primary steel can also be produced in EAFs when combined with direct reduction of iron ore with natural gas (DRI-EAF). This technology is commercially available with only small capacities in operation in the EU, but widely used in regions with access to cheap natural gas (Iran, Russia, and Saudi Arabia) (Material Economics, 2019; Midrex, 2019).

Adopting and advancing direct reduction processes, so that hydrogen could be used instead of natural gas, is the most advanced decarbonization option for primary steel. By using hydrogen, the energy demand might increase slightly compared to DRI with natural gas, though the emission intensity could be reduced to less than $0.4 \mathrm{tCO}_{2}$ per ton of steel (Chevrier, 2020; Toktarova et al., 2020). While the process using purely hydrogen is still in pilot phase (TRL = 5) (Agora Energiewende \& Wuppertal Institut, 2019) and the most advanced European project HYBRIT produces 1 t/hour (Pei et al., 2020), some interviewees stated that a transitional approach using both natural gas and hydrogen is feasible (Chevrier, 2020; Tenova, 2018). One technology provider suggested that already 2-8 Mt of such DRI capacity could be added per year from 2021 onwards, but that installation projects of at least 28-30 months could delay the technology implementation. Recent literature estimates investment costs for hydrogen-based DRI-EAF could be at $574 €$ per ton of annual capacity including hydrogen electrolysis (Vogl et al., 2018). Interviewees stated costs for such integrated sites to be closer to $900 €$ per ton, more than double the greenfield construction of new BF-BOF plants. Access to low-cost climate-friendly hydrogen is the principal operational cost uncertainty.

Some interviewees prefer financing for efficiency measures and carbon capture and storage solutions (CCS) for existing processes until long-term solutions are fully developed and cost competitive. Top gas recycling (BFBOF + TGR) could help to reduce emissions by 60\% (Fischedick et al., 2014; IEAGHG, 2013) and coal could be partially substituted with climate-friendly hydrogen or biomass (Mandova et al., 2019). Although the emission reduction potential of these options is limited (Fick et al., 2014), some interviewees consider a combination of these options as efficient for reducing emissions on the short term, given that green hydrogen will not be available over the next years. These considerations, though, disregard concerns about biomass supply and social acceptance of geological carbon dioxide storage (Terwel \& ter Mors, 2015). Over the next years investments in these options are considered likely, but public support directed towards these areas should not preclude the required shift towards carbon neutral production technologies.

Enhanced recycling of steel was mentioned by two interviewees. The availability of scrap is projected to grow significantly reflecting the increased construction and manufacturing volumes in recent decades (Material Economics \& Klevnas, 2018). A major barrier for more recycling is steel alloys with elements like nickel and chrome, which are difficult to segregate from elemental iron. Additionally, steel scrap is contaminated, for example with residual copper from wires. Consequently, scrap is usually downcycled to lower quality steel. Today, sorting processes for end-of-life products to separate scrap into different alloys are not sufficiently used (Material Economics \& Klevnas, 2018). Better technologies for sorting, separating, or processing scrap may be able to mitigate this issue, but need additional financial support (Allwood et al., 2019b). Indirect emissions of EAFs could be reduced by contracting low-emission electricity.

\subsection{Cement}

With an annual production of $179.8 \mathrm{Mt}$ (2018), cement is the most produced basic material in Europe (CEMBUREAU, 2020a). Highly standardized multistage dry kiln designs account for almost all EU production. The clinkering process requires temperatures of more than $1400^{\circ} \mathrm{C}$ and best practice installations have a thermal energy demand of $2.8 \mathrm{GJ} / \mathrm{t}$ (Chan \& Kantamaneni, 2015), resulting in fuel and process-based emissions of about 0.67 $\mathrm{tCO}_{2}$ per ton of cement (Schorcht et al., 2013). Various energy sources can be used, like petroleum coke, 
coal, natural gas, domestic waste, non-toxic industrial waste, or biomass. Since energy consumption is the main cost driver for cement making, sourcing differs substantially in EU member states and is driven by the local availability and cost (de Beer et al., 2017). Most emissions from cement production originate from calcination of limestone in the kiln, which means that deep decarbonization cannot be achieved by only switching to lowemission fuels (Scrivener et al., 2018).

Short-term improvements in the cement industry are based on using more biomass and waste, lowcarbon clinker, and additives to substitute clinker (CEMBUREAU, 2020b). All these options can be realized with todaýs kiln technology and do not require major investments. Changing the clinker composition to reduce its emission intensity is technologically feasible, but requires consensus on the revision of current concrete standards (Shanks et al., 2019). Interviewees highlighted that the development of alternative binders, e.g. Celitement (Achternbosch et al., 2016), is promising, but still in early development phases. Increasing the biomass share is difficult due to the available feedstock quality, since dust, nitrogen oxides $\left(\mathrm{NO}_{\mathrm{x}}\right)$ and sulphur dioxide $\left(\mathrm{SO}_{2}\right)$ emissions are to be avoided (Schorcht et al., 2013). Carbon capture will be needed to reduce emissions further and major pilots are in operation or planned in Europe (Agora Energiewende \& Wuppertal Institut, 2019). Interviewees confirmed that end-of-pipe measures, such as amine scrubbing (MEA), require an investment of about 76 million Euros per plant of $1 \mathrm{Mt} / \mathrm{a}$ capacity (Voldsund et al., 2019), which could potentially be combined with direct solidification of $\mathrm{CO}_{2}$ using residual concrete (Monteiro et al., 2018). This is significantly cheaper than the investment needed for the LEILAC pilot project, which can capture $95 \%$ of process related emissions with a new calciner design without significantly increasing the energy demand (Hills et al., 2017). Oxyfuel combustion has been implemented in industrial pilots and could be installed during major refurbishment campaigns (Lindemann Lino et al., 2018). Energy consumption increases slightly, but remains significantly lower than for MEA, making it one of the most economic capture alternatives (Voldsund et al., 2019). Interviewees highlighted that capture technologies are ready for implementation, but the usage of captured emissions is one of the main barriers for implementation. Some applications of $\mathrm{CO}_{2}$ as feedstock are explored in the chemical industry, but its suitability to produce synthetic e-fuels is limited since fossil emissions would be released to the atmosphere during their subsequent combustion. Furthermore, storage options continue to face high uncertainties regarding cost and social acceptance (Lipponen et al., 2017).

Secondary production of cement by recycling construction waste remains negligible and residuals are used in landfills or as filling material for new construction sites (van Lieshout, 2015). Recovered cementitious materials could be re-used and, with current best practices, up to $30 \%$ of limestone feed could be replaced (Allwood et al., 2019a). One interviewee indicated that enhanced sorting solutions are available and could be implemented in about $25 \%$ of Germany's stationary recycling sites at investment costs of $0.5-10$ M€ per plant by 2025 , making such solutions a potentially cost competitive alternative to primary production. Innovative separation processes include the SmartCrusher, which was implemented in an industrial scale pilot in 2013 and could recover higher shares of clinker from construction waste (SmartCrusher, 2013), replacing some primary cement production (Allwood et al., 2019a).

\subsection{Chemicals}

The chemical industry is a multifaceted sector with a wide range of different process routes and final products. However, most emissions are caused by processing fossil hydrocarbons. About $60 \%$ of direct and indirect emissions are linked to steam cracking and distillation of ethane and naphtha into its derivatives (ethylene, propylene, and other aromatics). Natural gas conversion to ammonia and methanol (via hydrogen) is responsible for another $10 \%$ of emissions, while the remaining emissions are related to process heat provision $(\mathrm{VCl}, 2019)$.

BAT for naphtha steam cracking between $750^{\circ} \mathrm{C}$ and $950^{\circ} \mathrm{C}$ requires $13.6 \mathrm{GJ} / \mathrm{t}$ of thermal energy, of which 1.4 $\mathrm{GJ} / \mathrm{t}$ can be recovered as process steam (IEA, 2018). In case of ethylene, building block for polymers and exemplary for other high value chemicals (HVC), an estimated $1.26 \mathrm{tCO}_{2} / \mathrm{t}$ of product are released (Neal et al., 2019). Ammonia and methanol are produced by combining catalytic steam reforming with high pressure reactions. During this process, natural gas is used to obtain hydrogen. BAT for ammonia production allows for a net energy consumption of $9.0 \mathrm{GJ} / \mathrm{t}$ (IEA, 2018). Based on data from Dutch ammonia plants, emission intensity is 
assumed to be $1.90 \mathrm{tCO}_{2} / \mathrm{t}$ of product and due to the relatively pure $\mathrm{CO}_{2}$ waste streams $60 \%$ of it can be captured without significant additional investments (Batool \& Wetzels, 2019).

Interviewees opted for technology options that would allow the production of high value chemicals without steam cracking. Methanol-to-olefin (MtO) technologies have been implemented on a commercial scale to produce fuels from natural gas via methanol (Hindman, 2017) and could also be used to produce olefins from bio-based feedstock (Phillips et al., 2011). The main barrier for MtO introduction is the availability of low-emission methanol, produced from biomass or climate-friendly hydrogen and captured $\mathrm{CO}_{2}$ (PérezFortes et al., 2016). Relative installation costs per ton of product for the MtO process is expected to be comparable to ammonia plants (IEA, 2018). Current pilot projects, such as Carbon2Chem (Deerberg et al., 2018) and Carbon4PUR (Carbon4PUR, 2017), focus on the use of captured industrial $\mathrm{CO}_{2}$ emissions as feedstock for high value chemicals.

Plastic causes about $4 \mathrm{tCO}_{2}$ emissions per ton of final product, while on average $0.5 \mathrm{tCO}_{2}$ per ton is released when incinerated at the end of its life (Zheng \& Suh, 2019). Although close to $30 \%$ of plastic waste is collected for recycling in the EU, recycled plastics only account for about $6 \%$ of today's material use in Europe (European Commission, 2018). The main barrier for increasing recycling rates and thereby reducing the demand of primary chemical production is the ability to sort and decompose polymers into different components.

Interviewees stated that improved mechanical recycling of plastic debris is technologically feasible but requires investments in state-of-the-art facilities with improved sensor-based sorting capabilities. According to literature, such installations consume between 2.7 and $4.6 \mathrm{GJ} / \mathrm{t}$ of mostly electric energy and are available for $400-700 € / t$ of capacity (IUT, 2019). Interviewees envisaged that this way $50-75 \%$ of packaging waste can be recovered. This is equivalent to $30-50 \%$ of all plastic waste in the EU (EPRS, 2017; European Commission, 2018).

Mechanical recycling is cost-effective but challenging for composite materials and raises concern of thermalmechanical degradation (Ragaert et al., 2017). By means of chemical recycling, molecules can be deconstructed into their initial components, which can be re-fed as feedstock into the primary production route. Different process alternatives exist. Pyrolysis is commercially available but requires pre-sorting of recycling streams. Hydrocracking is less feedstock sensitive, but still under development and requires external hydrogen supply (Solis \& Silveira, 2020). According to interviewees about $50 \mathrm{M} €$ per plant with an annual capacity between 20,000 and $30,000 \mathrm{t}$ is needed, making the technology more expensive than mechanical recycling. Commercial installations are currently under construction (Indaver, 2019) or in advanced piloting or realization phase (Lechleitner et al., 2020). The interviewees pointed to the emergence of a healthy competition between mechanical and different chemical recycling approaches. This expectation is also stated in the literature (Thunman et al., 2019).

Enzymatic biorecycling is another option mentioned by interviewees. This technology is being researched but not available at commercial scale, yet (Tournier et al., 2020). Like chemical recycling, depolymerization can be achieved. The advantages over chemical solutions are that process temperatures are relatively low and no organic solvents are used (Marty et al., 2019).

\subsection{Aluminium}

The production of aluminium is the most energy intensive process under investigation. Best available commercial processes consume about $65.5 \mathrm{GJ} / \mathrm{t}$ of aluminium, plus an additional $14 \mathrm{GJ} / \mathrm{t}$ if carbon-based anodes are seen as an energy source (Saevarsdottir et al., 2020). Aluminium is produced from Bauxite with Alumina as an intermediate product. Thermal energy used to refine Bauxite to Alumina is commonly supplied by natural gas but can be electrified, given the low temperatures of the Bayer process (180 $\left.{ }^{\circ} \mathrm{C}\right)(\mathrm{EA}, 2020 \mathrm{~b})$. Alumina is processed to aluminium via electrolysis, making aluminium production highly electricity intensive $(46.5 \mathrm{GJ} / \mathrm{t})$. Carbon anode consumption is the main source of emissions, so that even in case of decarbonized electricity supply, emissions of about 3-4 $\mathrm{tCO}_{2}$ per ton of aluminium remain (EA, 2020a; Material Economics, 2019).

Besides ensuring a fully renewable electricity supply, emissions can be limited by using carbon-free anodes, which would avoid $\mathrm{CO}_{2}$ emissions during aluminium smelting. So far, industrial-scale demonstration projects 
have not been implemented (Wyns \& Khandekar, 2019), though interviewees mentioned that a joint-venture of Rio Tinto and Alcoa plans to commercialize carbon-free electrodes using the ELYSIS technology by 2024 (ELYSIS, 2020). Another producer stated that this technology might not be market-ready until 2030 and expects that research and development costs for reaching TRL 8 will require funding of 50-100 M€. Optimized electrolysis technologies, which reduce energy demand by $15 \%$, have been implemented on an industrial scale in a Norwegian plant (Norsk Hydro, 2018).

Primary production accounts for less than $25 \%$ of EU aluminium production (EA, 2020a). For secondary production, the distinction must be made between the recycling of 'new scrap' and 'old scrap'. Resmelting of relatively pure industrial aluminium scrap consumes $1.4 \mathrm{GJ} / \mathrm{t}$ and emits $0.15 \mathrm{tCO}_{2} / \mathrm{t}$ of product. Recycling of composites and the wide range of alloying elements in processed aluminium require pre-treatment and often limit secondary production to downcycling, resulting in higher energy consumption $(2.2 \mathrm{GJ} / \mathrm{t})$ and emission intensity $\left(0.25 \mathrm{tCO}_{2} / \mathrm{t}\right)$. One interviewee stated that the cost for a new large scale recycling facility is about $270 \mathrm{M} €$, which roughly corresponds to the cost of a state-of-the-art facility that entered operation in Germany in 2014 (Waste Management World, 2014). Smaller specialized modular designs are available off-the-shelf from different technology providers (Light Metal Age, 2018).

Recycling is limited by the availability and purity of scrap. While between $90 \%$ and $95 \%$ of aluminium in automotive and buildings is recovered for recycling, more significant potential for increased recycling exists for packaging and beverage cans with current recycling rates of $60 \%$ and $75 \%$, respectively (EA, 2016, 2020a). The availability of post-consumer scrap is expected to grow significantly as increased per capita consumption over the past decades will be available in form of scrap. A significantly higher share of demand could be covered by recycled materials, but public support might be needed for the implementation of enhanced sorting technologies (e.g. Laser-Induced Breakdown Spectroscopy (LIBS)) (Material Economics \& Klevnas, 2018).

\subsection{Investment needs for climate-friendly materials during the recovery period}

The techno-economic review of climate-friendly technology options, summarized in Annex 1.2 shows that 'shovel-ready' alternative, climate-friendly technologies exist for all basic materials.

This allows for a first estimation of investment potentials in the European context during the recovery period. By contrasting insights obtained from interviewees and scientific literature, we define technological adoption rates for climate-friendly material options for each of the reviewed industries (Annex 1.3). If approximately $10 \%$ of today's primary production (base year: 2018) was replaced by low-emission technologies and an additional $5-10 \%$ of primary production (base year: 2018) was substituted by enhanced sorting and recycling options until 2025 total investments of 28.9 billion Euro would be needed (Figure 1). The proposed adoption rates slightly differ across sectors and are based on the current status of existing technologies.

They are also aligned with the process renewal cycles in the basic material sector with furnace design life spanning from 20 years in the steel industry (van Laar \& Corus, 2016) to 50 years in the cement sector (Habert et al., 2010). Investments in recycling and sorting processes represent new capacity additions. By proposed adoption rates for primary and secondary production a $20 \%$ share of climate-friendly basic materials could be reached without early retirement of existing installations by 2025 .

In addition, stated adoption rates are considered to be sufficiently large to create a business case for climatefriendly technology options, and thereby trigger a multiplier effect by creating business opportunities for technology providers and sorting and recycling industries.

Nevertheless, the proposed adoption rates are not a prescription, but rather an indication of the share of basic material production that can stem from climate-friendly production processes after 5 years of technological transition.

Support for shovel-ready alternative climate-friendly technologies as part of the recovery plan could therefore help to kick-start the transition and significantly reduce industrial emissions. Based on Annex 1.2, new primary production facilities have the potential to reduce the emission intensity of primary steel, aluminium, and petrochemical production by more than $90 \%$ and cement production by $80 \%$. However, this requires the use of zero-emission energy carriers and solutions for captured carbon emissions. Given that adjacent 


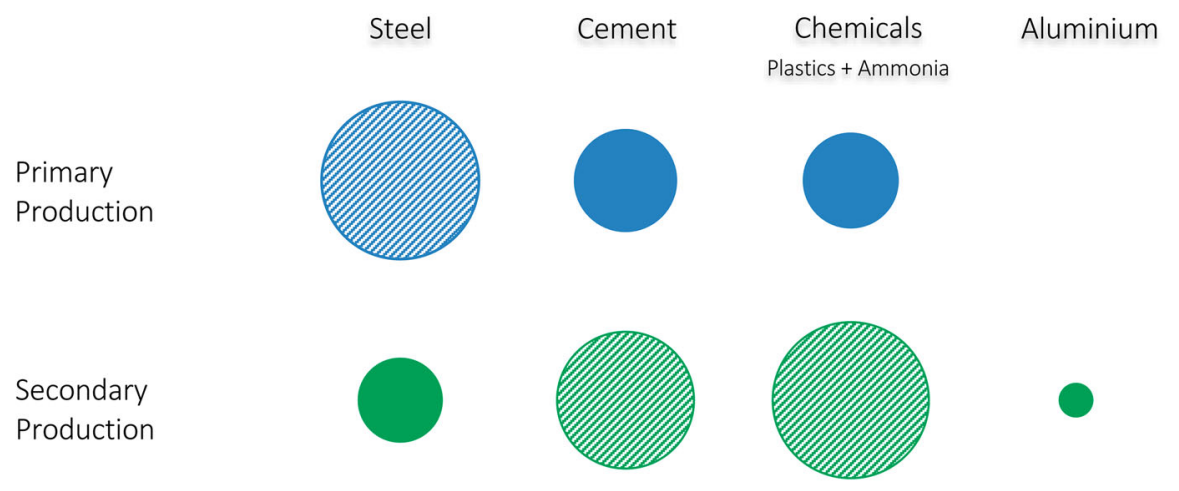

$=1$ Billion $€$

Total Investment: 28.9 Billion €

\begin{tabular}{|l|c|l|c|l|l|}
\cline { 2 - 6 } \multicolumn{1}{c|}{} & \multicolumn{3}{c|}{$\begin{array}{c}\text { Capacity replacements by new low-emission } \\
\text { primary processes relative to } 2018 \text { production }\end{array}$} & \multicolumn{2}{c|}{$\begin{array}{c}\text { Capacity additions new low-emission secondary } \\
\text { processes relative to } 2018 \text { production }\end{array}$} \\
\hline Steel & $10 \%$ & of EU primary production to be renewed & $10 \%$ & of EU primary replaced by secondary production \\
\hline Cement & $10 \%$ & of EU primary production retrofitted with CCS & $5 \%$ & of EU primary replaced by secondary production \\
\hline Plastics & $10 \%$ & of EU primary ethylene production renewed & $10 \%$ & of EU plastic demand additionally met with recycling \\
\hline Ammonia & $20 \%$ & of EU primary production retrofitted with CCS & & & \\
\hline Aluminium & & & $10 \%$ & of EU primary replaced by secondary production \\
\hline
\end{tabular}

Figure 1. Estimation of investment volumes and adoption rates until 2025 if existing production was replaced with new climate-friendly production processes (primary production and secondary production, relative to 2018 data). Cost data based on literature or (indicated as cross-hatched) estimates from interviewees.

technology and infrastructure are not available yet (e.g. climate-friendly hydrogen or carbon transport and storage), operation of these alternatives might rely on non-renewable energy and feedstock during the first years.

Optimized recycling technologies could potentially boost secondary production and reduce the need for emission- and energy-intensive primary production. Except for the cement sector, recycling processes are well-established, but the purity of waste streams needs to be improved to increase circularity and avoid downcycling. Estimating the impact of higher recycling shares is difficult. While in the long-run circularity can be emission-neutral for all reviewed industries, the emission intensity of the entire waste processing value chain until 2025 is beyond the scope of this study.

\section{Investment barriers}

The previous section has identified a set of technology options for climate-friendly production, enhanced sorting and recycling processes that can be supported as part of the recovery package. However, the interviews disclosed that barriers for implementing these technologies exist. Six main barriers were identified and ranked in order of importance, as visualized in Figure 2 and presented in the following.

\subsection{Lack of effective and predictable carbon pricing mechanisms}

A major barrier for four out of five of the interviewees was that climate-friendly options are not competitive with conventional technologies due to ineffectiveness and uncertainty of current carbon pricing mechanisms. Interviewees, especially from the steel industry, stated that elevated and stable carbon prices are crucial for investing in technologies with long design life, while operating using hydrogen or other low-emission energy 


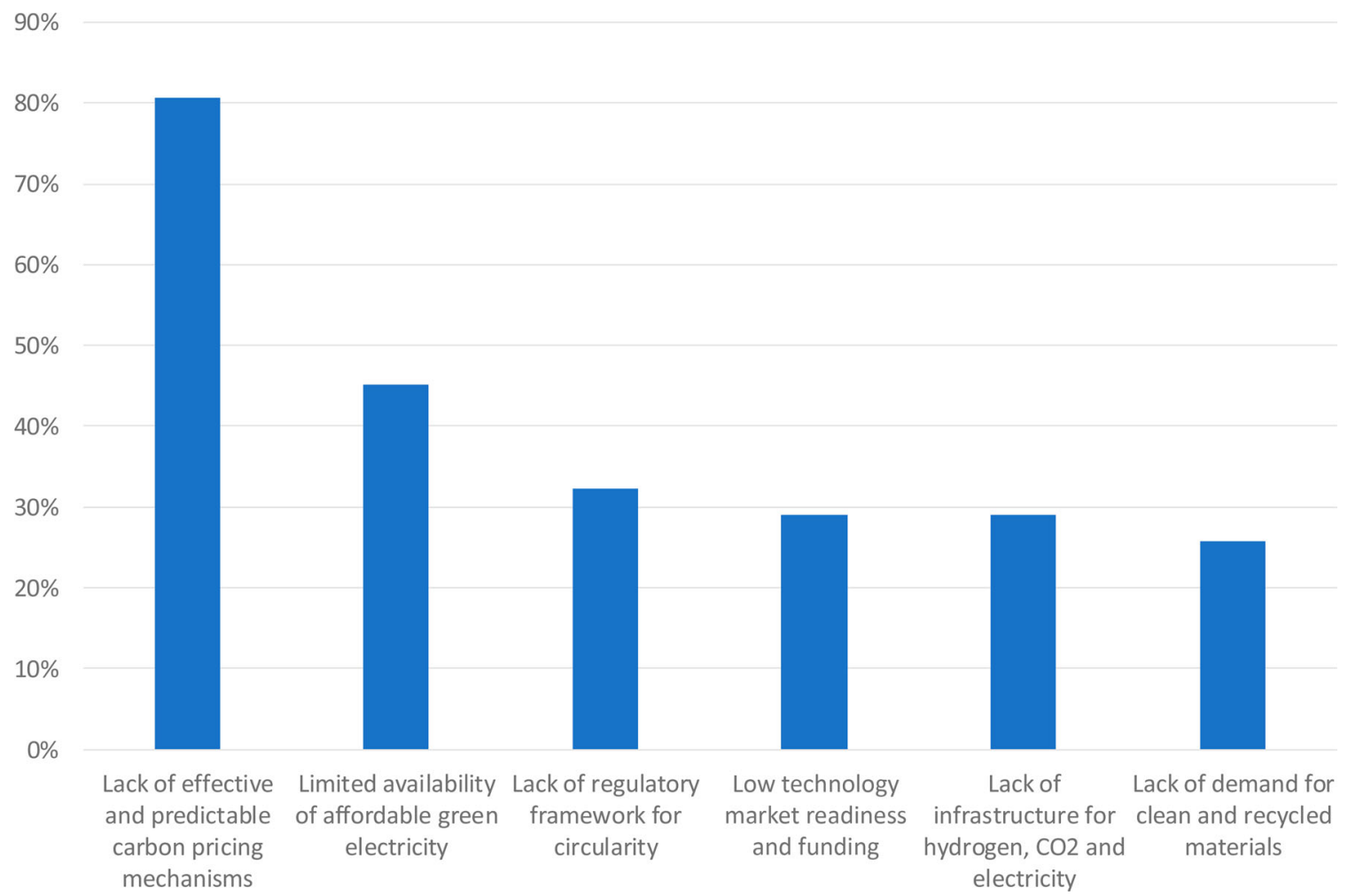

Figure 2. Ranking of barriers based on interviewees responses.

feedstock and energy carrier. In case of carbon capture, elevated carbon prices are needed to recover both investment and operational costs.

The investors' confidence in carbon price levels which compensate for the additional costs of clean production processes is limited. In this context, carbon leakage concerns were emphasized by almost two thirds of the interviewees. Increasing carbon prices and declining levels of free allowance allocation could cause an asymmetric cost burden for EU producers. Economic survival of the domestic industry could be prioritized over a more stringent EU ETS cap, lowering the credibility of high carbon prices. Due to the ongoing free allowance allocation, only a small and uncertain share of EU ETS carbon costs is passed on into the supply chain with a negligible impact on end-consumer prices (Neuhoff \& Ritz, 2019). As a result, only limited incentives for material efficiency, material substitution and use of recycled materials are created.

Furthermore, uncertainty regarding future carbon prices is considered to be a major project risk, which increases the option value of current assets and incentivises to postpone investment decisions and wait for regulatory changes (Venmans, 2016).

\subsection{Limited availability of affordable green electricity}

Almost half of the interviewees stated that the limited access to cheap low-emission electricity is a major barrier for the deployment of climate-friendly material production. As most of the latter imply a switch from fossil energy carriers to electricity, companies would be more exposed to electricity price uncertainty. Electricity markets are expected to be more volatile due to increasing shares of intermittent solar and wind generation (Gerres et al., 2019b), while long-term renewable power purchase agreements (PPA) require contractual stipulations addressing supply volatility of renewables (Baines et al., 2019). The unpredictability of future low-carbon electricity prices contributes to the operational cost uncertainty of low-carbon technologies and represents an additional project risk. 


\subsection{Lack of regulatory framework for circularity}

One third of interviewees highlighted the lack of a policy framework to support circularity. One issue is the missing focus on lifecycle emissions of basic materials, which is perceived as an important barrier for the competitiveness of enhanced sorting and recycling. Some interviewees stated that insufficient emissions accounting for the incineration of plastic waste hinders investments in enhanced sorting and recycling. In case of cement, one interviewee indicated that the lack of effective landfill fees for construction waste disincentivises increased sorting and recycling efforts.

Some interviewees considered the regulatory framework for biomass and captured industrial $\mathrm{CO}_{2}$ use to be underdeveloped. Others, including all interviewed sorting and recycling companies, emphasized barriers for closed-loop recycling, mentioning that the feasibility of the latter declines with an increasing variety of composites, alloys, and additives (European Commission, 2018). Current regulation, such as the Ecodesign Directive (2009/125/EC), and in-service collection systems were considered insufficient to provide homogenous content and consistent quality of recoverable materials within waste streams. Interviewees also mentioned a lack of coordination between recyclers and potential consumers regarding standards and quality requirements for recycled materials.

\subsection{Low technology market readiness and funding}

Almost one third of all interviewees and the majority of those from the chemical industry indicated that climatefriendly technologies have not reached the technology market readiness level for investment in large-scale pilots or commercial projects. Some interviewees mentioned difficulties in scaling up alternative processes. While individual components and sub-processes might have a high TRL, process integration has not been done on an industrial scale, so far, which results in a significant project risk.

Sizeable funding is required to bring innovation from market readiness to industrial scale implementation (Nemet et al., 2018), but few public funding options exist at national and EU levels. Private firms are reluctant to invest if the break-even period for profitability is highly uncertain, the investment volumes are relatively large, process integration has not been done before, patents offer limited protection and profitable leadmarkets for green commodities are not available. Failure of construction projects represents a major risk for private sector companies, as can be observed for investments in the latest generation of nuclear power plants in the US and France (Marignac, 2015; Morgan et al., 2018).

\subsection{Lack of infrastructure for hydrogen, $\mathrm{CO}_{2}$ and electricity}

Almost one third of interviewees referred to the unavailability of transport infrastructure for hydrogen, power and $\mathrm{CO}_{2}$ as a major barrier. The transition towards climate-friendly basic materials is perceived as a classic 'chicken-and-egg' problem. Without certainty about the development of the needed infrastructure, companies will not invest in changing processes.

\subsection{Lack of demand for clean and recycled materials}

Similarly, as mentioned by about one quarter of the interviewees, including all those active in sorting and recycling, without sufficient demand for climate-friendly products, there are scarce investment incentives for climate-friendly production, enhanced sorting and recycling.

\section{Discussion: policies to unlock investments during the recovery period}

The previous sections highlighted that barriers of technological, economic, and regulatory nature hinder investments in climate-friendly technologies. These barriers are exacerbated by the current crisis which creates uncertainty about the timeline and scale of the recovery, forcing companies to reduce expenditures, including innovation funding. In this section we present the elements of a policy package that could help overcome 
these barriers. Some policies aim at breaking the inertia towards the transition also via recovery funding. Other policies are needed to ensure a long-term framework favourable for investments in these technologies and should accompany the recovery package to give credibility to investors that the business case will last beyond the recovery timeframe.

\subsection{Ensuring effective and predictable carbon pricing}

The most important perceived barrier by interviewees is the lack of an effective and stable carbon pricing mechanism that ensures the long-term competitiveness of climate-friendly production and closed-loop recycling both domestically and abroad. This can be addressed by the following policies that should accompany the recovery package.

\subsubsection{Full carbon cost internalization and carbon leakage protection}

For climate-friendly production processes to be cost-competitive, a carbon pricing mechanism is needed that meets two main requirements. First, it should be robust to carbon leakage risk, so that carbon price levels can credibly reach the level of incremental costs of climate-friendly production processes. Second, the carbon cost of conventional processes needs to be reflected in product prices so that consumers of materials pay for emissions and climate-friendly producers can recover incremental decarbonization costs. Full carbon cost internalization along the value chain is needed to create the full incentives for climate-friendly options (Neuhoff \& Ritz, 2019).

Past reforms of the EU ETS reduced the level of free allocation to cut emissions while securing carbon leakage protection by awarding free allowances. Achieving these two objectives with one instrument alone has not been possible (Cosbey et al., 2020). A new reform of the EU ETS is urgent, and one of the priorities of the new European Commission. Two options are currently being discussed (Felbermayr \& Peterson, 2020):

A trade-based approach would introduce border carbon adjustments (BCAs) to address carbon leakage risks in combination with a shift to full auctioning of emission allowances to achieve full carbon cost internalization. A variety of design options exist. BCAs could only cover imports, which might trigger concerns for exportoriented industries since they would face higher costs than their international competitors. Continued free allocation for export-oriented industries could, in turn, result in a limited carbon cost pass-through and persistent regulatory uncertainty. As a border-related approach, it may also trigger international retaliations and challenges under the World Trade Organisation (WTO) (Monjon \& Quirion, 2011). Alternatively, a symmetric BCA could reimburse the carbon costs for goods exported to other jurisdictions, thereby providing a better carbon leakage protection for the domestic industry without continued free allocation. The implementation would require a high level of international coordination with WTO-type agreements to secure robustness to appeals by individual countries.

A consumption-based approach would continue the benchmark-based free allowance allocation for the industry, but combined with a Climate Contribution, i.e. an excise charge on basic materials and material-intensive end-products (e.g. cars). Such extra charge would be passed along the value chain and paid upon final consumption (regardless of whether produced domestically or abroad). The charge would be tied to the weight of the material at the same benchmark used for free allowance allocation. Such approach would combine full carbon leakage protection with an effective carbon price signal to all actors along the value chain. Building on experiences with other consumption charges, implementation would be WTO-compatible and administratively feasible rendering this approach more viable for the recovery period (Ismer et al., 2020).

\subsubsection{Hedging against carbon price uncertainty}

Regulatory risks, and in particular carbon price uncertainty, are perceived investment barriers. Carbon Contracts for Differences (CCfDs) issued by governmental financial institutions can help investors in climate-friendly production and recycling processes to hedge against regulatory and carbon market risks, thereby covering increased operational costs of climate-friendly processes (Richstein, 2017). Based on a contractually agreed strike price for emission reductions relative to the sector benchmark, investors are guaranteed a fixed revenue per ton of non-emitted $\mathrm{CO}_{2}$. As long as EU ETS prices are below the strike price, the difference 
between strike price and market price is reimbursed. If $\mathrm{CO}_{2}$ prices exceed the strike price investors must return additional earnings to avoid windfall profits. Besides improving the financial security of climate-friendly investments, CCfDs reduce financing costs and companies are incentivised to not delay investments until EU ETS prices stabilize at higher level. CCfDs may reduce the need for public funding since government expenditures might be partially or fully recuperated if $\mathrm{CO}_{2}$ prices rise (Sartor \& Bataille, 2019).

\subsection{Securing availability of affordable green electricity}

The lack of sufficient affordable green electricity is a major barrier and points to the importance of a continued policy focus on renewable deployment as part of a recovery plan. Public auctions for renewable Contracts for Differences (CfDs) are one option to eliminate regulatory uncertainties and allow project developers to secure low-cost financing, thus reducing power generation costs. With lower electricity costs, lower carbon price levels are required for climate-friendly basic material production processes to compete with conventional ones (Vogl et al., 2018). Auctions for public renewable CfDs or for publicly backed PPAs also help to accelerate investments in wind and solar energy by eliminating the option value of delaying investments due to electricity market uncertainties (Neuhoff et al., 2018). This is particularly relevant during the recovery period with increased demand uncertainty and declining credit rating of signing parties in private PPAs.

\subsection{Increasing regulatory focus on circularity}

Closing the loop and upcycling waste streams require targeted policy measures that should be implemented together with the recovery package. First, feedstock availability for recycling processes could be improved by pricing the carbon emissions of waste incineration and disposal as landfill, creating incentives for implementing enhanced sorting technologies. An advanced disposal fee on materials could ensure cost internalization. This fee could be partially returned in case of closed-loop recycling, thereby changing material choices within the production and packaging industry as well as increase recycling efforts for plastic (Joltreau, 2018).

Second, existing environmental legislation like the Ecodesign Directive (2009/125/EC) needs to be aligned with policy objectives of closed-loop recycling and enhanced repair and reuse. This encompasses tighter rules on product lifetime, reparability, and material use. By homologizing material use for certain applications, e.g. alloys used for beverage cans, sorting can be facilitated and downcycling avoided. In case of plastic packaging the use of additives should be carefully re-evaluated to ensure that functionality does not come at the expenses of further recyclability (European Commission, 2018). To be effective, these measures need to be aligned with clearly defined recycling targets as well as transparent metrics for tracking material streams within the recycling loop.

\subsection{Reaching technology market readiness}

NextGenerationEU, the European Union Recovery Instrument adopted in 2020, consisting of 750 billion Euros for actions to be launched in 2021-2023 and implemented by $2026,{ }^{2}$ could support firms unlocking investments in near-market ready technologies and first-of-a-kind industrial implementation. In particular, the budget increase of InvestEU by 5.6 billion Euros could be suited to support larger-scale demonstration plants and first-of-a-kind projects with high technological readiness, but without any experience in their industrial scale implementation and operation. Funds shall also be directed to the digitalization of sorting and recycling plants, which would allow for better monitoring and optimization of material flows. The increased budget of Horizon Europe by 5 billion Euros could help to bring technologies towards market readiness, which are currently in pilot phase, possibly in combination with member states funding windows, including as part of the Recovery and Resilience Facility and Just Transition Fund. ${ }^{3}$

In order to help low-emission technologies to overcome the valley of death and allow for a timely implementation of projects, regulatory hurdles such as complex requirements and lengthy approval processes need to be addressed via a coordinated effort by relevant regulatory bodies (Pelkmans \& Renda, 2014). 


\subsection{Providing infrastructure}

Countering the 'chicken-and-egg' problem requires adequate infrastructure to meet the potential demand for climate-friendly options. Large-scale infrastructure projects could possibly be developed in Public-Private Partnerships (Kwak et al., 2009). Commissioning and financing these projects as part of the national and EU recovery packages (e.g. through the enhanced Just Transition Mechanism (Widuto \& Jourde, 2020)) and ensuring a low carbon footprint of projects would not only create jobs and demand for climate-friendly materials, but also give a credible signal to investors.

\subsection{Creating demand for climate-friendly and recycled material}

As stabilizing high carbon prices in the 2030 horizon are uncertain (Perino \& Willner, 2017), it is important to create short-term demand and lead markets for climate-friendly and recycled materials as part of the recovery plan.

Labels can nudge climate-aware consumers into low-carbon choices (Galarraga et al., 2020). Standards on product design can also play an important role to enhance demand of climate-friendly options (Scott et al., 2018). However, so far most European labelling and standardization requirements are not aligned with climate goals since their focus lies primarily on safety and functionality rather than environmental considerations (Gerres et al., 2021). A timely revision of product design regulation as discussed in Section 5.3 can support enhanced recycling as part of a climate-friendly recovery plan.

Quotas may oblige companies to use an increasing share of recycled materials (recyclates) in their production processes. This could help to address the future demand uncertainty for sorting and recycling companies, which is seen as a main barrier by interviewees (Section 4.6). Quotas have already been adopted for recycled content in plastic beverage bottles by Directive (EU) 2019/904 and additional recycling requirements are envisaged for other plastic packaging, construction materials and vehicles (EC, 2020). At the same time, some companies have already committed to such quotas on a voluntary basis (e.g. Ellen MacArthur Foundation \& UN Environment, 2019).

Green Public Procurement practices that take into account the carbon footprint of products can allow governments and other public bodies to leverage their purchasing decisions to create demand for climate-friendly and recycled materials, and incentivise material efficiency in product design, construction and manufacturing (Kadefors et al., 2020). This can be of high relevance for a green recovery. Not just infrastructure projects, but also measures to reduce the impact of climate change, such as coastal protection, are often material- and labour-intensive. Procuring these projects under the recovery package could boost the demand for lowcarbon and recycled materials. The same applies for climate-friendly private or public-private construction projects, such as wind farms and recycling plants, or transport infrastructure for hydrogen, power and $\mathrm{CO}_{2}$, which, as mentioned, are potentially in the scope of the recovery package.

\subsection{Limitations of this research}

The research presented in this work is of timely relevance in light of the COVID-19 recovery and it bridges recent academic contributions with insights from industrial stakeholders. Nevertheless, due in part to the timely nature, our analysis is subject to some limitations.

First, the geographic spread of interviews was not balanced, with about half of interviewees based in Germany. This implies that the analysis cannot reflect relevant cross-country differences, e.g. with regard to availability of carbon storage options or low-cost renewable electricity, which to some extent emerged from the interviews. As such, results might be biased towards the German context and perspective.

Second, slightly different interview approaches were adopted by different research teams in different countries. Despite the coding being peer-reviewed with the researchers conducting the interviews, fully uniform information handling across interviews in different countries cannot be guaranteed.

Third, many of the interviewees did not answer the questions concerning expected investments until 2025 and relative costs. Therefore, the quantification of costs relies primarily on figures reported in literature and only 
partially on information provided by interviewees, as detailed in Annexes 1.2 and 1.3. Thus, the economic figures and assumptions of technology adoption until 2025 should be considered rough estimates.

These issues can be addressed by future research. A repetition of the survey involving a larger and more uniform sample size per country could reflect country-specific characteristics. In addition, an interview design more tailored to extract information on investment potential and costs might improve robustness and comprehensiveness. Updated cost assessment should additionally include infrastructure investments, which while currently excluded, are seen as an important area of recovery funding. Nevertheless, the results presented here identify the most important areas of sector-specific funding needs for the basic material sector and can therefore provide valuable insights for both academia and policy makers to further design targeted - recovery and post-recovery - policy measures.

\section{Conclusion}

The COVID-19 pandemic has caused an unprecedented economic crisis, which has motivated governments around the globe to announce plans for stimulating the industrial recovery. Focused on the EU recovery plan, this work highlights the necessity to align recovery policies with long-term decarbonization targets to avoid carbon lock-in in the basic materials sector.

Insights obtained from industrial stakeholder interviews and a literature review demonstrate that options for the climate-friendly basic material production, sorting and recycling are shovel-ready and could be implemented during the recovery period. Based on technological readiness of alternative processes and feasible adoption rates in the steel, cement, aluminium, and plastics sectors it is estimated that up to $20 \%$ of EU current basic material production can be switched to such low-emission options by 2025, requiring investments of approximately 28.9 billion Euros. This could permit primary production processes to reduce their emissions by $80-90 \%$ compared to best available technology options in use today. Further emission intensity improvements of the basic materials sector can be obtained by increasing recycling rates. Supporting these investments could not only kick-start the decarbonization of the sector, but also trigger an economic multiplier effect, thereby contributing to recovery objectives.

Nevertheless, the paper finds that there is currently no business case for these climate-friendly options in the basic materials sector. Besides elevated investment costs, main barriers are linked to highly uncertain operational costs, demand uncertainty and the dependency on yet-to-be developed infrastructure, e.g. for hydrogen.

Recovery funding by itself will therefore be insufficient to trigger these investments, and it should be complemented by a set of policies - as reviewed in the paper - that address these barriers and ensure a robust business case beyond the recovery period. Such policies could include a revision of the EU ETS integrating a Climate Contribution, project-based Carbon Contracts for Differences, auctions for publicly backed Contracts for Difference and Power Purchasing Agreements, green public procurement and public-private partnerships, and a revision of regulation (e.g. on product design) to improve circularity. While the study focuses on the post-COVID recovery of the European basic materials sector, results can be useful to inform policy discourses on recovery and decarbonization in other jurisdictions given the global relevance of both issues.

\section{Notes}

1. TRL as used by the European Commission (Annex G of the General Annexes to the EC Work Programme 2016/17), ranging from TRL 1 - basic principle observed to TRL 9 - actual system proven in operational environment. This review focuses on technologies of TRL 6 - technology demonstrated in relevant environment, and higher.

2. Council Regulation (EU) 2020/2094 of 14 December 2020 established a European Union Recovery Instrument to support the recovery in the aftermath of the COVID-19 crisis OJ L 433I, 22.12.2020, pp. 23-27.

3. The majority of the EU recovery funding will be dedicated to the Recovery and Resilience Facility (672.5 billion Euros, including 312.5 billion Euros of grants) and made available to member states which determine the allocation of these funds with their National Recovery and Resilience Plans. EU funding options beyond recovery funding remain available as additional sources of financing. 


\section{Acknowledgements}

The authors of the report would like to thank Johan Rootzén (Chalmers University of Technology), Johanna Lehne (E3G), Per Klevnäs (Material Economics), Mats Kröger (DIW Berlin), Xi Sun (DIW Berlin), Florian Ausfelder (DECHEMA) for their valuable inputs and feedback on previous versions of the document, as well as all the interviewees for their time and support including in providing additional materials.

\section{Disclosure statement}

No potential conflict of interest was reported by the author(s).

\section{Funding}

The authors acknowledge funding and co-funding from the European Climate Foundation (ECF) through the Climate Friendly Materials Platform project, the C4U project (Horizon 2020 Grant Agreement No. 884418) and the Swedish Foundation for Strategic Environmental Research through the Mistra Carbon Exit Program.

\section{ORCID}

Olga Chiappinelli (iD http://orcid.org/0000-0002-4100-6025

Heleen de Coninck (D) http://orcid.org/0000-0001-6410-5539

Timo Gerres (D) http://orcid.org/0000-0001-9245-8032

Karsten Neuhoff (iD http://orcid.org/0000-0002-0582-8072

Balázs Felsmann (D) http://orcid.org/0000-0003-2704-5703

Eugénie Joltreau (iD http://orcid.org/0000-0001-7709-2503

Pedro Linares (D) http://orcid.org/0000-0002-0572-1937

Jörn Richstein (iD http://orcid.org/0000-0003-2758-9962

Jan Stede (D) http://orcid.org/0000-0003-4081-8950

\section{References}

Achternbosch, M., Dewald, U., Nieke, E., \& Sardemann, G. (2016). New calcium hydrosilicate-based cements: Celitement - A technology assessment. ZKG International, 69(6), 48-57.

Agora Energiewende \& Wuppertal Institut. (2019, November). Klimaneutrale Industrie: Schlüsseltechnologien und Politikoptionen für Stahl, Chemie und Zement.

Åhman, M., Nilsson, L. J., \& Johansson, B. (2016). Global climate policy and deep decarbonization of energy-intensive industries. Climate Policy, 17(5), 634-649. https://doi.org/10.1080/14693062.2016.1167009

Allwood, J., Azevedo, J., Clare, A., Cleaver, C., Cullen, J., Dunant, C., Fellin, T., Hawkins, W., Horrocks, I., Horton, P., Ibell, T., Lin, J., Low, H., Lupton, R., Murray, J., Salamanti, M., Cabrera Serrenho, A., Ward, M., \& Zhou, W. (2019a, November). Absolute zero. Apollo University of Cambridge Repository. Retrieved December 3, 2019, from https://www.repository.cam.ac.uk/handle/1810/299414

Allwood, J., Dunant, C., Lupton, R., \& Cabrera Honorio Serrenho, A. G. (2019b, March). Steel arising: Opportunities for the UK in a transforming global steel industry. Apollo - University of Cambridge Repository. Retrieved September 30, 2020, from https://www. repository.cam.ac.uk/handle/1810/294350

Baines, S., Wrubell, S., Kennedy, J., Bohn, C., \& Richards, C. (2019). \#HowToPPA: An examination of the regulatory and commercial challenges and opportunities arising in the context of private power purchase agreements for renewable energy. Alberta Law Review, 57(2), 389. https://doi.org/10.29173/alr2580

Bataille, C., Åhman, M., Neuhoff, K., Nilsson, L. J., Fischedick, M., Lechtenböhmer, S., Solano-Rodriquez, B., Denis-Ryan, A., Stiebert, S., Waisman, H., Sartor, O., \& Rahbar, S. (2018). A review of technology and policy deep decarbonization pathway options for making energy-intensive industry production consistent with the Paris Agreement. Journal of Cleaner Production, 187, 960-973. https:// doi.org/10.1016/j.jclepro.2018.03.107

Batool, M., \& Wetzels, W. (2019, March). Decarbonisation options for the Dutch fertiliser industry. PBL Netherlands Environmental Assessment Agency.

Büttner, S. M., Schneider, C., Piccolroaz, C., Sauer, A., \& König, W. (2020). How does the German manufacturing industry react to the calls to decarbonise? Industrial Efficiency 2020: Decarbonise Industry!.

Carbon4PUR. (2017). Carbon4PUR. Retrieved September 30, 2020, from https://www.carbon4pur.eu/

CEMBUREAU. (2020a). Activity report 2019. European Cement Association. Retrieved September 21, 2020, from https://cembureau.eu/ media/clkdda45/activity-report-2019.pdf 
CEMBUREAU. (2020b). Cementing the European green deal: Reaching climate neutrality along the cement and concrete value chain by 2050. Retrieved September 30, 2020, from https://cembureau.eu/media/kuxd32gi/cembureau-2050-roadmap_final-version_web. pdf

Chan, Y., \& Kantamaneni, R. (2015). Study on energy efficiency and energy saving potential in industry and on possible policy mechanisms. ICF Consulting.

Chevrier, V. (2020). Transitioning to the hydrogen economy. Direct from Midrex, vol. 1st Quarter 2020. Retrieved September 18, 2020, from https://www.midrex.com/wp-content/uploads/Midrex-2020-DFM1QTR-Final.pdf

Cosbey, A., Droege, S., Fischer, C., Gerres, T., Ismer, R., Linares, P., Mehling, M., Neuhoff, K., Pirlot, A., Sato, M., \& Śniegocki, A. (2020, April). Designing border carbon adjustments and alternative measures: An overview.

de Beer, J., Cihlar, J., Hensing, I., \& Zabeti, M. (2017, April). Status and prospects of co-processing of waste in EU cement plants. Ecofys, Cembureau. Retrieved September 22, 2020, from https://cembureau.eu/media/rjqiyqca/2017-05-11_ecofys_publication_ alternativefuels_report.pdf

de Bruyn, S., Jongsma, C., Kampman, B., Görlach, B., \& Thie, J.-E. (2020, July). Energy-intensive industries: Challenges and opportunities in energy transition. CE Delft, European Parliament's Committee on Industry, Research and Energy (ITRE).

Deerberg, G., Oles, M., \& Schlögl, R. (2018). The project Carbon2Chem ${ }^{\oplus}$. Chemie Ingenieur Technik, 90(10), 1365-1368. https://doi.org/ 10.1002/cite. 201800060

EA. (2016). Recycling aluminium: A pathway to a sustainable economy. European Aluminium. Retrieved May 9, 2019, from https:// www.european-aluminium.eu/media/1712/ea_recycling-brochure-2016.pdf

EA. (2019). European aluminium vision 2050: A vision for strategic, low carbon and competitive aluminium. European Aluminium. Retrieved October 14, 2020, from https://www.european-aluminium.eu/media/2545/sample_vision-2050-low-carbon-strategy_ 20190401.pdf

EA. (2020a). Circular aluminium action plan: A strategy for achieving aluminum's full potential for circular economy by 2030. European Aluminium. Retrieved September 30, 2020, from https://european-aluminium.eu/media/2903/european-aluminium-circularaluminium-action-plan.pdf

EA. (2020b, June). EU strategies on energy sector integration \& hydrogen: Position on the European commission's policy roadmaps. European Aluminium.

EC. (2020). Circular economy action plan: For a cleaner and more competitive Europe. European Commission. https://ec.europa.eu/ environment/circular-economy/pdf/new_circular_economy_action_plan.pdf

Ellen MacArthur Foundation \& UN Environment. (2019). Cew plastic economy global commitment: June 2019 report. Retrieved October 1, 2020, from https://www.newplasticseconomy.org/assets/doc/GC-Report-June19.pdf

ELYSIS. (2020). Carbon-free aluminium: A new era for the aluminium industry. ELYSIS. Retrieved September 28, 2020, from https://www. elysis.com/en/elysis

EPRS. (2017). Towards a circular economy: Waste management in the EU. Publications Office, IP/G/STOA/FWC/2013-001/LOT 3/C3. Retrieved September 30, 2020, from https://data.europa.eu/doi/10.2861/978568

EUROFER. (2013). A steel roadmap for a low carbon Europe 2050. The European Steel Association. Retrieved June 22, 2017, from http:// www.nocarbonnation.net/docs/roadmaps/2013-Steel_Roadmap.pdf

EUROFER. (2019, November). Low carbon roadmap: Pathways to a CO2-neutral European steel industry. Retrieved September 11, 2020, from https://www.eurofer.eu/assets/Uploads/EUROFER-Low-Carbon-Roadmap-Pathways-to-a-CO2-neutral-European-SteelIndustry.pdf

European Commission. (2018). Communication from the Commission to the European Parliament, the Council, the European Economic and Social Committee and the Committee of the Regions. A European strategy for plastics in a circular economy. COM/2018/028. Retrieved September 30, 2020, from https://eur-lex.europa.eu/resource.html?uri=cellar:2df5d1d2-fac7-11e7-b8f501aa75ed71a1.0001.02/DOC_1\&format=PDF

Felbermayr, G., \& Peterson, S. (2020, April). Economic assessment of carbon leakage and carbon border adjustment. Policy Department for External Relations Directorate General for External Policies of the Union, PE 603.501. Retrieved October 19, 2020, from https:// www.europarl.europa.eu/RegData/etudes/BRIE/2020/603501/EXPO_BRI(2020)603501_EN.pdf

Fick, G., Mirgaux, O., Neau, P., \& Patisson, F. (2014). Using biomass for pig iron production: A technical, environmental and economical assessment. Waste and Biomass Valorization, 5(1), 43-55. https://doi.org/10.1007/s12649-013-9223-1

Fischedick, M., Marzinkowski, J., Winzer, P., \& Weigel, M. (2014). Techno-economic evaluation of innovative steel production technologies. Journal of Cleaner Production, 84, 563-580. https://doi.org/10.1016/j.jclepro.2014.05.063

Galarraga, I., Kallbekken, S., \& Silvestri, A. (2020). Consumer purchases of energy-efficient cars: How different labelling schemes could affect consumer response to price changes. Energy Policy, 137, 111181. https://doi.org/10.1016/j.enpol.2019.111181

Gerres, T., Chaves, J. P., Linares, P., \& Gómez, T. (2019a). A review of cross-sector decarbonisation potentials in the European energy intensive industry. Journal of Cleaner Production, 210, 585-601. https://doi.org/10.1016/j.jclepro.2018.11.036

Gerres, T., Chaves, J. P., Martínez, F., Rivier, M., Cossent, R., Sánchez, Á., Gómez, T. (2019b). Rethinking the electricity market design: Remuneration mechanisms to reach high RES shares. Results from a Spanish case study. Energy Policy, 129, 1320-1330. https://doi. org/10.1016/j.enpol.2019.03.034

Gerres, T., Haussner, M., Neuhoff, K., \& Pirlot, A. (2021). To ban or not to ban carbon-intensive materials: A legal and administrative assessment of product carbon requirements Review of European, Comparative \& International Environmental Law, 1-14. https:// doi.org/10.1111/reel.12395

Grubb, M. (2014). Planetary economics: Energy, climate change and the three domains of sustainable development (1st ed.). Routledge. 
Habert, G., Billard, C., Rossi, P., Chen, C., \& Roussel, N. (2010). Cement production technology improvement compared to factor 4 objectives. Cement and Concrete Research, 40(5), 820-826. https://doi.org/10.1016/j.cemconres.2009.09.031

Hills, T. P., Sceats, M., Rennie, D., \& Fennell, P. (2017). LEILAC: Low cost CO2 capture for the cement and lime industries. Energy Procedia, 114, 6166-6170. https://doi.org/10.1016/j.egypro.2017.03.1753

Hindman, M. (2017, October). ExxonMobil methanol to gasoline (MTG). https://www.globalsyngas.org/uploads/downloads/S6-2ExxonMobil\%20Catalysts-Mitch\%20Hindman.pdf

IEA. (2018, October). The future of petrochemicals - Methodological annex. International Energy Agency.

IEA. (2020). Tracking industry 2020. Retrieved February 5, 2021, from https://www.iea.org/reports/tracking-industry-2020

IEAGHG. (2013, April). Overview of the current state and development of CO2 capture technologies in ironmaking process. International Energy Agency (IEA).

Indaver. (2019, October 15). Press release: Indaver receives permit to build a new plant for the chemical recycling of end-of-life plastics. Retrieved September 30, 2020, from https://www.indaver.ie/en/media-and-downloads/news-detail/press-release-indaverreceives-permit-to-build-a-new-plant-for-the-chemical-recycling-of-end-of-lif/

Ismer, R., Neuhoff, K., \& Pirlot, A. (2020). Border carbon adjustments and alternative measures for the EU ETS an evaluation (Vol. 1855). IUT. (2019, December). Study about plastic sorting and recycling. COWI. Retrieved September 23, 2020, from https://plastikviden.dk/ media/212448/study-about-plastic-sorting-and-recycling.pdf

Janipour, Z., de Nooij, R., Scholten, P., Huijbregts, M. A. J., \& de Coninck, H. (2020). What are sources of carbon lock-in in energy-intensive industry? A case study into Dutch chemicals production. Energy Research \& Social Science, 60, 101320. https://doi.org/10.1016/ j.erss.2019.101320

Joltreau, E. (2018). Pricing products' negative externalities at end-of-life using eco-modulation: Discussion from case studies. Economics and policy of energy and the environment.

Kadefors, A., Lingegård, S., Uppenberg, S., Alkan-Olsson, J., \& Balian, D. (2020). Designing and implementing procurement requirements for carbon reduction in infrastructure construction - International overview and experiences. Journal of Environmental Planning and Management, 64(4), 611-634. https://doi.org/10.1080/09640568.2020.1778453

Material Economics \& Klevnäs, P. (2018, June). The circular economy - A powerful force for climate mitigation. Material Economics. Retrieved June 6, 2018, from https://media.sitra.fi/2018/05/04145239/material-economics-circular-economy.pdf

Kröger, M., Xi, S., Chiappinelli, O., Clemens, M., May, N., Neuhoff, K., \& Richstein, J. (2020, May). A green new deal after corona: What we can learn from the financial crisis. DIW, 4. https://www.diw.de/documents/publikationen/73/diw_01.c.788843.de/diw_focus_4.pdf

Kwak, Y. H., Chih, Y., \& lbbs, C. W. (2009). Towards a comprehensive understanding of public private partnerships for infrastructure development. California Management Review, 51(2), 51-78. https://doi.org/10.2307/41166480

Lechleitner, A., Schwabl, D., Schubert, T., Bauer, M., \& Lehner, M. (2020). Chemisches Recycling von gemischten Kunststoffabfällen als ergänzender Recyclingpfad zur Erhöhung der Recyclingquote. Österreichische Wasser- und Abfallwirtschaft, 72(1-2), 47-60. https:// doi.org/10.1007/s00506-019-00628-w

Light Metal Age. (2018, February 15). Aludium orders multi-chamber furnace for recycling painted scrap. Light Metal Age Magazine. Retrieved September 28, 2020, from https://www.lightmetalage.com/news/industry-news/recycling-remelt/aludium-ordersmulti-chamber-furnace-for-recycling-painted-scrap/

Lindemann Lino, M., Böhm, M., Hoening, V., Ruppert, J., Becker, S., \& Mathai, R. (2018, August). Analysis of oxyfuel clinker cooler operational performance (D9.2). H2020 CEMCAP. Retrieved September 22, 2020, from https://www.sintef.no/globalassets/project/ cemcap/presentasjoner/d9.2_revision1_final.pdf

Lipponen, J., McCulloch, S., Keeling, S., Stanley, T., Berghout, N., \& Berly, T. (2017). The politics of large-scale CCS deployment. Energy Procedia, 114, 7581-7595. https://doi.org/10.1016/j.egypro.2017.03.1890

Mandova, H., Patrizio, P., Leduc, S., Kjärstad, J., Wang, C., Wetterlund, E., Kraxner, F., \& Gale, W. (2019). Achieving carbon-neutral iron and steelmaking in Europe through the deployment of bioenergy with carbon capture and storage. Journal of Cleaner Production, 218, 118-129. https://doi.org/10.1016/j.jclepro.2019.01.247

Marignac, Y. (2015, May 11). French nuclear issues - A focus on some recent developments. Retrieved June 5, 2018, from https://pdfs. semanticscholar.org/presentation/266e/f81438d725b5f3736a701fe330c9d54f52f2.pdf

Marty, A., Tournier, V., Duquesne, S., \& André, I. (2019). Addressing the problem of plastic waste: Development of an enzymatic process for PET recycling. ECI Symposium Series. https://dc.engconfintl.org/enzyme_xxv/113

Material Economics. (2019). Industrial transformation 2050: Pathways to net-zero emissions from EU heavy industries. Material Economics. Retrieved April 26, 2019, from https://materialeconomics.com/latest-updates/industrial-transformation-2050

Midrex. (2019, July). 2018 World direct reduction statistics. Retrieved June 10, 2020, from https://www.midrex.com/wp-content/ uploads/Midrex_STATSbookprint_2018Final-1.pdf

Monjon, S., \& Quirion, P. (2011). A border adjustment for the EU ETS: Reconciling WTO rules and capacity to tackle carbon leakage. Climate Policy, 11(5), 1212-1225. https://doi.org/10.1080/14693062.2011.601907

Monteiro, J., Goetheer, E., Schols, E., van Os, P., Calvo, J. F. P., Hoppe, H., Bharadwaj, H. S., Roussanaly, S., Khakharia, P., Feenstra, M., \& de Jong, A. (2018, April). Post-capture CO2 management: Options for the cement industry (D5.1). H2020 CEMCAP.

Morgan, M. G., Abdulla, A., Ford, M. J., \& Rath, M. (2018). US nuclear power: The vanishing low-carbon wedge. Proceedings of the National Academy of Sciences, 115(28), 7184-7189. https://doi.org/10.1073/pnas.1804655115

Neal, L. M., Haribal, V. P., \& Li, F. (2019). Intensified ethylene production via chemical looping through an exergetically efficient redox scheme. iScience, 19, 894-904. https://doi.org/10.1016/j.isci.2019.08.039 
Nemet, G. F., Zipperer, V., \& Kraus, M. (2018). The valley of death, the technology pork barrel, and public support for large demonstration projects. Energy Policy, 119, 154-167. https://doi.org/10.1016/j.enpol.2018.04.008

Neuhoff, K., May, N., \& Richstein, J. C. (2018). Renewable energy policy in the age of falling technology costs (Vol. 1746).

Neuhoff, K., \& Ritz, R. (2019, October). Carbon cost pass-through in industrial sectors. Cambridge Working Papers in Economics, vol. 1988. Retrieved October 1, 2020, from https://www.repository.cam.ac.uk/bitstream/handle/1810/299473/cwpe1988.pdf? sequence $=1$ \&isAllowed $=\mathrm{y}$

Norsk Hydro. (2018). Facts about the Karmøy technology pilot. Retrieved September 28, 2020, from https://www.hydro.com/ Document/Index?name=Facts\%20Karm\%C3\%B8y\%20technology\%20pilot.pdf\&id=5845

Pei, M., Petäjäniemi, M., Regnell, A., \& Wijk, O. (2020). Toward a fossil free future with HYBRIT: Development of iron and steelmaking technology in Sweden and Finland. Metals, 10(7), 972. https://doi.org/10.3390/met10070972

Pelkmans, J., \& Renda, A. (2014, November). Does EU regulation hinder or stimulate innovation? 96.

Pérez-Fortes, M., Schöneberger, J. C., Boulamanti, A., \& Tzimas, E. (2016). Methanol synthesis using captured CO2 as raw material: Techno-economic and environmental assessment. Applied Energy, 161, 718-732. https://doi.org/10.1016/j.apenergy.2015.07.067

Perino, G., \& Willner, M. (2017). EU-ETS phase IV: Allowance prices, design choices and the market stability reserve. Climate Policy, 17 (7), 936-946. https://doi.org/10.1080/14693062.2017.1360173

Phillips, S. D., Tarud, J. K., Biddy, M. J., \& Dutta, A. (2011, January). Gasoline from wood via integrated gasification, synthesis, and methanol-to-gasoline technologies. NREL/TP-5100-47594, 1004790. Retrieved May 27, 2020, from http://www.osti.gov/servlets/purl/ 1004790-PNHiXm/

Ragaert, K., Delva, L., \& Van Geem, K. (2017). Mechanical and chemical recycling of solid plastic waste. Waste Management, 69, 24-58. https://doi.org/10.1016/j.wasman.2017.07.044

Richstein, J. C. (2017). Project-based carbon contracts: A way to finance innovative low-carbon investments. DIW Discussion Papers, 1714. http://doi.org/10.2139/ssrn.3109302

Rissman, J., Bataille, C., Masanet, E., Aden, N., Morrow, W. R., Zhou, N., Elliott, N., Dell, R., Heeren, N., Huckestein, B., Cresko, J., Miller, S. A., Roy, J., Fennell, P., Cremmins, B., Blank, T. K., Hone, D., Williams, E. D., de la Rue du Can, S., ... Helseth, J. (2020). Technologies and policies to decarbonize global industry: Review and assessment of mitigation drivers through 2070. Applied Energy, 266, 114848. https://doi.org/10.1016/j.apenergy.2020.114848

Saevarsdottir, G., Kvande, H., \& Welch, B. J. (2020). Aluminum production in the times of climate change: The global challenge to reduce the carbon footprint and prevent carbon leakage. JOM, 72(1), 296-308. https://doi.org/10.1007/s11837-019-03918-6

Sartor, O., \& Bataille, C. (2019). Decarbonising basic materials in Europe: How carbon CONTRACTS-for-difference could help bring breakthrough technologies to market. IDDRI, Study 06/19. https://www.iddri.org/sites/default/files/PDF/Publications/Catalogue\% 20lddri/Etude/201910-ST0619-CCfDs_0.pdf

Schorcht, F., Kourti, I., Scalet, B. M., Roudier, S., \& Delgado-Sancho, L. (2013). Best available techniques (BAT) reference document for the production of cement, lime and magnesium oxide: Industrial emissions directive 2010/75/EU (integrated pollution prevention and control). Publications Office of the European Union, JRC. Retrieved January 25, 2018, from http://dx.publications.europa.eu/10. $2788 / 12850$

Scott, K., Roelich, K., Owen, A., \& Barrett, J. (2018). Extending European energy efficiency standards to include material use: An analysis. Climate Policy, 18(5), 627-641. https://doi.org/10.1080/14693062.2017.1333949

Scrivener, K. L., John, V. M., \& Gartner, E. M. (2018). Eco-efficient cements: Potential economically viable solutions for a low-CO2 cement-based materials industry. Cement and Concrete Research, 114, 2-26. https://doi.org/10.1016/j.cemconres.2018.03.015

Shanks, W., Dunant, C. F., Drewniok, M. P., Lupton, R. C., Serrenho, A., \& Allwood, J. M. (2019). How much cement can we do without? Lessons from cement material flows in the UK. Resources, Conservation and Recycling, 141, 441-454. https://doi.org/10.1016/j. resconrec.2018.11.002

SmartCrusher. (2013, October). Smart crusher: Results lab crusher and pilot installation. Retrieved September 22, 2020, from https:// slimbreker.nl/downloads/100\%20procent\%20Circulair\%20Beton\%20door\%20Slim\%20Breken.pdf

Solis, M., \& Silveira, S. (2020). Technologies for chemical recycling of household plastics - A technical review and TRL assessment. Waste Management, 105, 128-138. https://doi.org/10.1016/j.wasman.2020.01.038

Tenova, H. Y. L. (2018, December). Technological achievements, experience and trends in H2-based steelmaking. San Nicolás de los Garza.

Terwel, B. W., \& ter Mors, E. (2015). Host community compensation in a carbon dioxide capture and storage (CCS) context: Comparing the preferences of Dutch citizens and local government authorities. Environmental Science \& Policy, 50, 15-23. https://doi.org/10. 1016/j.envsci.2015.01.015

Thunman, H., Vilches, T. B., Seemann, M., Maric, J., Vela, I. C., Pissot, S., \& Nguyen, H. N. T. (2019). Circular use of plastics-transformation of existing petrochemical clusters into thermochemical recycling plants with $100 \%$ plastics recovery. Sustainable Materials and Technologies, 22, e00124. https://doi.org/10.1016/j.susmat.2019.e00124

Toktarova, A., Karlsson, I., Rootzén, J., \& Odenberger, M. (2020, May). Technical roadmap steel industry. Chalmers University of Technology; University of Gothenburg; Mistra Carbon Exit.

Tournier, V., Topham, C. M., Gilles, A., David, B., Folgoas, C., Moya-Leclair, E., Kamionka, E., Desrousseaux, M.-L., Texier, H., Gavalda, S., Cot, M., Guémard, E., Dalibey, M., Nomme, J., Cioci, G., Barbe, S., Chateau, M., André, I., Duquesne, S., \& Marty, A. (2020). An engineered PET depolymerase to break down and recycle plastic bottles. Nature, 580(7802), 216-219. https://doi.org/10.1038/s41586020-2149-4 
van Laar, R., \& Corus, D. (2016). Modern blast furnace design. In Millenium steel 2016 (pp. 35-40). Retrieved June 2, 2017, from http:// millennium-steel.com/wp-content/uploads/2016/05/pp035-040_ms16.pdf

van Lieshout, M. M. (2015). Update Prioritering handelings-perspectieven verduurzaming betonketen 2015. CE Delft. Retrieved June 16, 2017, from http://mvonederland.nl/sites/default/files/media/CE_Delft_2A59_Update_Prioritering_handelingsperspectieven_ verduurzaming_betonketen_DEF\%20(2).pdf

VCI. (2019). Roadmap Chemie 2050 auf dem Weg zu einer treibhausgasneutralen chemischen Industrie in Deutschland: eine Studie von DECHEMA und FutureCamp für den VCl. Retrieved September 30, 2020, from https://edocs.tib.eu/files/e01fn19/1682254917.pdf

Venmans, F. M. J. (2016). The effect of allocation above emissions and price uncertainty on abatement investments under the EU ETS. Journal of Cleaner Production, 126, 595-606. https://doi.org/10.1016/j.jclepro.2016.02.108

Vogl, V., Åhman, M., \& Nilsson, L. J. (2018). Assessment of hydrogen direct reduction for fossil-free steelmaking. Journal of Cleaner Production, 203, 736-745. https://doi.org/10.1016/j.jclepro.2018.08.279

Voldsund, M., Anantharaman, R., Berstad, D., De Lena, E., Fu, C., Gardarsdottir, S. O., Jamali, A., Pérez-Calvo, J.-F., Romano, M., Roussanaly, S., Ruppert, J., Stallmann, O., \& Sutter, D. (2019, October). Comparative techno-economic analysis of CO2 capture in cement plants (D4.6). H2020 CEMCAP.

von der Leyen, U. (2020, September 16). State of the union address by President von der Leyen at the European Parliament plenary. Retrieved October 14, 2020, from https://ec.europa.eu/commission/presscorner/detail/en/SPEECH_20_1655

Waste Management World. (2014, October 10). Worlds largest aluminium recycling plant opened in Germany. Retrieved September 28, 2020, from https://waste-management-world.com/a/worlds-largest-aluminium-recycling-plant-opened-in-germany

Wesseling, J. H., \& Van der Vooren, A. (2017). Lock-in of mature innovation systems: The transformation toward clean concrete in the Netherlands. Journal of Cleaner Production, 155, 114-124. https://doi.org/10.1016/j.jclepro.2016.08.115

Widuto, A., \& Jourde, P. (2020, October). Just transition fund. European Parliamentary Research Service, Briefing.

World Steel. (2019). Steel statistical yearbook 2019. World Steel Association. Retrieved March 17, 2020, from https://www.worldsteel. org/en/dam/jcr:7aa2a95d-448d-4c56-b62b-b2457f067cd9/SSY19\%2520concise\%2520version.pdf

Wyns, T., \& Khandekar, G. (2019). Metals for a climate neutral Europe: A 2050 blueprint. IES-VUB and Eurometaux. Retrieved September 30, 2020, from https://www.ies.be/files/Metals_for_a_Climate_Neutral_Europe.pdf

Zheng, J., \& Suh, S. (2019). Strategies to reduce the global carbon footprint of plastics. Nature Climate Change, 9(5), 374-378. https:// doi.org/10.1038/s41558-019-0459-z 